\title{
MARPASAR DALAM PERSPEKTIF TEOLOGI KRISTEN
}

\author{
Simon \\ Sekolah Tinggi Teologi Salatiga \\ Korespondensi:petrus.simon26@yahoo.com \\ Ricu Sele \\ Sekolah Tinggi Teologi Happy Family Surabaya \\ selegideon777@gmail.com
}

\begin{abstract}
The term "Marpasar" is a place of mention in the Batak language which is determined as a person who earns a living by lending money. Marpasar becomes pros and cons for some members of the congregation and also clergy is based on theological and non-theological reasons. The theological reason is that in the Old Testament there was a prohibition about lending money. While nontheological reasons, the image of Marpasar perpetrators as loan sharks or extortionists have been formed in the public view due to high-interest rates. This article focuses on discussing Marpasar and how exactly the meaning of the Bible verse about the interest of money. The method used by researchers is a qualitative descriptive approach to exposition, interviews and literature. The results of the discussion obtained an answer that the context of the verses used is used by contra parties differing in context, a culture of geography in the present, and not all actors in Marpasar peg the interest that leads to extortion.
\end{abstract}

Keywords: marpasar, interest, money, customer, moneylenders

\begin{abstract}
Abstrak
Istilah kata Marpasar adalah suatu penyebutan dalam bahasa Batak yang didefinisikan sebagai orang yangmencari nafkah dengan cara membungakan uang. Marpasar menjadi pro kontra bagi sebagain kalangan jemaat dan juga rohaniawan didasarkan pada alasan teologis dan non teologis. Adapun alasan teologis karena dalam Perjanjian Lama adanya larangan tentang membungakan uang. Sementara alasan non-teologis, citra pelaku Marpasar sebagai lintah darat atau pemeras sudah terbentuk di pandangan umum karena bunga yang dipatok tinggi. Artikel ini berfokus membahas tentang Marpasar serta bagaimana sebenarnya maksud dari ayat Alkitab tentang membungakan uang. Adapun metode yang digunakan peneliti adalah deskriptif kualitatif dengan pendekatan eksposisi, wawancara serta literatur. Hasil dari pembahasan didapatkan sutau jawaban bahwa konteks ayat-ayat yang digunakan digunakan oleh pihak yang kontra berbeda secara konteks, zaman, budaya serta kultur geografi di masa kini, serta tidak semua pelaku Marpasar mematok bunga yang mengarah pada pemerasan.
\end{abstract}

Kata-Kata Kunci: marpasar, bunga, uang, nasabah, rentenir 


\section{Pendahuluan}

Pro-kontra di kalangan jemaat dan sebagian para pendeta mengenai etiskahkah menggeluti pekerjaan Marpasar ditanggapi secara berbeda-beda. Ada yang menyetujui asal masih dalam tahap kewajaran pembungaannya, namun ada juga yang sama sekali menolak dengan tegas bahwa pekerjaan marpasar tidak boleh sama sekali. Golongan yang tidak menyetujui pekerjaan Marpasar didasarkan pada alasan-alasan teologis dan alasan nonteologis. Adapun alasan teologis itu dengan mengutif ayat-ayat Alkitab mencari nafkah dengan cara membungakan uang yang dilakukan oleh mereka yang menggeluti pekerjaan ini bertentangan dengan firman Tuhan. Pihak yang kontra mengemukakan alasan teologisnya dalam Imamat 25:36-37; Ulangan 23:10; Nehemia 5:7, 10 dan Amsal 28:8, sudah jelas mengungkapkan membungakan uang tidak dibenarkan. Pihak-pihak yang berseberangan mengungkapkan ayat-ayat Alkitab di atas sudah secara jelas menolak keberadaan pelaku Marpasar yang membungakan uang sebagai dasar mencari nafkah. Misalnya informan AD sebagai pihak yang kontra menyatakan "dalam imamat 25:37 jelas dikatakan tentang larangan riba (membungakan uang), sekalipun di dalam PL namun hukum itu tetap relevan dengan hukum kasih." 1 Alasan nonteologis dari pihak yang kontra mengungkapkan mereka yang menggeluti pekerjaan Marpasar ini sering membuat bunganya mencekik ketika si debitur (peminjam) menerima pinjaman. Tidak hanya bunga yang tinggi, para pemberi pinjaman kerap melakukan tindakan-tindakan yang kurang toleran seperti mengambil secara paksa barang yang berharga debitur (peminjam) bila tidak bisa membayar cicilan pinjaman yang telah disepakati.

Golongan yang pro mengemukakan menggeluti pekerjaan Marpasar tidaklah salah selama dilakukan dengan cara-cara yang benar serta bunga pinjaman yang diberikan kepada peminjam (debitur) masih dalam tahap kewajaran. Tahap kewajaran dapat dimaknai dengan bunga tidak terlalu tinggi, adanya kesepakatan antara pemberi pinjaman (pekerja Marpasar) dengan debitur sebagai penerima pinjaman sebelum kesepakatan tercipta dalam bertransaksi. Pendapat senada dikemukakan oleh informan ES, masalah cuma cara pandang saja. Pada umumnya pihak yang kontra melihat para pekerjaan Marpasar itu bunga tinggi, dan cara penagihan sedikit kejam, mungkin itu yg membuat mereka tidak setuju. Padahal kalau bunga tidak tinggi dan cara penagihan baik, akan begitu membantu orang, dari pada meminjam di leasing. ${ }^{2}$ Penulis kembali melakukan wawancara dengan bertanya kepada informan AS, mengungkapkan bahwa dari sisi logika, bila pihak pemberi pinjaman memberikan uangnya kepada debitur (peminjam) dilakukan atas dasar kesepakatan bersama sebelum "transaksi", tentu itu masih tahap kewajaran. Bagaimanapun pihak pemberi pinjaman membutuhkan tambahan uang dari yang diberi kepada pihak peminjam karena pihak pemberi pinjaman sudah ada pengeluaran seperti bensin, tenaga, dan sebagainya. ${ }^{3}$

Pada umumnya orang menilai yang menggeluti pekerjaan Marpasar ini berasal dari Suku Batak. Akan tetapi citra pekerja Marpasar dari suku Batak mulai memudar seiring beragamnya berbagai suku di Indonesia yang menjadikan Marpasar sebagai mata pencarian. Yeyen Parlina mengungkapkan pada umumnya ada kesamaan antara rentenir di satu pasar

1Wawancara dengan informan AD pada hari Jumat 16 Agustus 2019 melalui chatting messenger facebook pada pukul 19.55 WIB.

${ }^{2}$ Ada dua makna leasing pertama, (kredit barang) suatu perjanjian di mana lessor (pihak yang menyewakan) suatu perangkat alat perusahaan (mesin-mesin) termasuk service, pemeliharaan dan lain-lain kepada lessee (penyewa) untuk suatu jangka waktu tertentu. Kedua, kontrak sewa atau system penyewaan barang modal dalam kurun waktu tertentu sesuai dengan perjanjian tertulis. Wawancara dengan informan ES, pada hari Jumat 16 Agustus 2019, pukul 19.45 WIB melalui chat messenger.

${ }^{3}$ Wawancara dengan informan AS pada hari Sabtu 17 gustus 2019 melalui telephon. 
dengan pasar lainnya. Di setiap pasar, ada rentenir yang berasal dari Medan yang mereka sebut sebagai Wong Batak, orang Cina, dan orang Jawa. ${ }^{4}$

Marpasar pada masa kini sudah bagian dari sebuah profesi dalam mencari nafkah. Dikatakan sebuah profesi karena Marpasar kini keberadaannya hampir ada di setiap provinsi khususnya di pasar-pasar tradisional di seluruh Indonesia. Malahan pekerjaan Marpasar telah menjadi alternatif dalam penyerapan jumlah pengangguran. Marpasar menjadi lapangan pekerjaan buat orang-orang yang mempunyai sejumlah modal (kecil atau besar) yang mau meminjamkan uangnya kepada orang lain, demikian juga membuka peluang bagi para peminjam uang untuk membuka usaha (bagi yang mau berusaha) atau sekedar mengembangkan usahanya. Para pekerja Marpasar pun kerap mengalami tekanan batin baik dari lingkup masyarakat maupun dalam lingkup gerejawi. Dalam lingkup masyarakat yang majemuk, keberadaan pelakunya terkadang dipandang sinis serta dicap sebagai "lintah darat" karena membungakan uang. Sementara dalam lingkup gereja, sebagian jemaat maupun rohaniawan mengutif ayat-ayat Alkitab untuk menyindir bahkan tidak terlibat dalam melayani karena dianggap belum layak hanya karena mereka menggeluti pekerjaan Marpasar.

Bagaimana sebenarnya tanggapan Alkitab mengenai membungakan uang yang dilakukan oleh pekerja Marpasar? Bila di dalam Alkitab Perjanjian Lama tertulis larangan membungakan uang, sudah tepatkah ayat-ayat itu jika secara prinsip hermeneutik diterapkan di masa kini, padahal secara kondisi, budaya, keadaan sosial di PL berbeda dengan masa sekarang? Jika ayat-ayat tersebut ditafsir secara harafiah lalu diimplementasikan oleh golongan yang menentang pekerjaan Marpasar, bukankah bank, koperasi juga membungakan uang? Sekalipun bank, koperasi, maupun lembaga keuangan sejenisnya mempunya legitimasi hukum dalam penetapan bunga, tetapi jika penafsiran Alkitab secara literal diterapkan tentu lembaga-lembaga keungan itu salah karena Alkitab mengemukakan agar jangan membungakan uang. Pendapat senada dikemukakan oleh Nurhadi, kontroversi bunga bank masih mewarnai wacana yang hidup di masyarakat. Dikarenakan bunga yang diberikan oleh bank merupakan sesuatu yang diharamkan menurut Majelis Ulama Indonesia (MUI) sejak tahun 2003 lalu. Namun, wacana ini masih saja membumi ditelinga, dikarenakan beragam argumentasi yang dikemukakan untuk menghalalkan bunga, bahwa bunga tidak sama dengan riba. ${ }^{5}$

Artikel ini berfokus membahas ayat-ayat Alkitab khususnya dalam Perjanjian Lama yang sering dijadikan landasan teologis oleh mereka yang kontra tidak diperkenankannya menggeluti pekerjaan Marpasar. Selain penulis menguraikan dari PL, bagaimana pandangan Perjanjian Baru mengenai Marpasar juga dibahas dalam artikel ini. Diharapkan dari pembahasan ini ada tujuan yang diperoleh yaitu adanya suatu kejelasan secara teologis tentang topik ini, serta artikel ini menjadi sumber penambah informasi golongan yang kontra maupun yang pro mengenai pekerjaan Marpasar.

\section{Metode Penelitian}

Menurut Dedy Mulyana metode adalah proses, prinsip dan prosedur yang digunakan untuk suatu pendekatan dalam mengkaji topik penelitian hingga mencari jawaban. ${ }^{6}$ Dalam penulisan artikel ini, metode yang peneliti gunakan adalah metode

4Yeyen Parlina, "Praktik Pinjaman Rentenir Dan Perkembangan Usaha Pedagang Di Pasar Prapatan Panjalin Majalengka," Inklusif (Jurnal Pengkajian Penelitian Ekonomi Dan Hukum Islam) Vol. 2, no. 2 (2017): 128.

52.

${ }^{5}$ Nurhadi, “Bunga Bank Antara Halal Dan Haram," Nur El-Islam, Vol 4, No 2, oktober 2017,

${ }^{6}$ Dedy Mulyana, No Metode Penelitian (Bandung: Rosdakarya, 2002), 120. 
deskriptif kualiatif dengan pendekatan eksposisi, wawancara, sertapenggunaan berbagai literatur dalam menambah perbendaharaan data. Zaluchu menyatakan, dilihat dari instrumen penelitian yang menjadi alat pengumpulan data serta analisis, penelitian kualitatif banyak menggunakan data yang bersifat deskriptif seperti daftar wawancara, laporan hasil pengamatan lapangan, transkrip-transkrip pembicaraan, dan catatan-catatan pengamatan. ${ }^{7}$ Eksposisi dilakukan untuk menjelaskan ayat-ayat yang dipergunakan oleh golongan yang kontra tidak bolehnya Marpasar.

Eksposisi adalah analisis terhadap nats yang diperluas dengan tafsiran dan ilustrasi. Sebagai sebuah kegiatan, eksposisi masih berada pada taraf penafsiran atas ayat-ayat berdasarkan penelitian yang seksama, meliputi kata-kata dan ungkapan-ungkapan yang dipakai sambil memperhatikan konteks dekat dan jauh, serta latar belakang sejarah dan geografinya. ${ }^{8}$ Sedangkan wawancara dilakukan untuk mendapatkan informasi dari pelaku pekerja Marpasar mengenai seluk-beluk dalam mereka melakukan transaksi. Menurut Emzir wawancara dapat didefinisikan sebagai interaksi bahasa yang berlangsung antara dua orang dalam situasi saling berhadapan salah seorang, yaitu yang melakukan wawancara meminta informasi atau ungkapan kepada orang yang diteliti yang berputar di sekitar pendapat dan keyakinannya. ${ }^{9}$ Adapun yang akan menjadi objek wawancara dalam penelitian artikel ini adalah pertama, para pekerja marpasar. Kedua, golongan yang kontra dan tidak kontra mengenai isu di artikel ini. Model wawancara yang dilakukan oleh penulis dalam artikel ini beragam, baik dengan bertanya secara langsung kepada responden, baikwawancara melalui telephone, Whatsapp maupun chatting messenger. Diharapkan dengan mendeskripsikan mengenai pekerjaan Marpasar, kemudian menganalisa ayat-ayat Alkitab melalui eksposisi, adanya pemahaman secara komperenshif didapatkan.

\section{Hasil dan Pembahasan}

\section{Arti Marpasar}

Penggunaan istilah kata "Marpasar" sebenarnya adalah suatu istilah dalam bahasa Batak yang diartikan sebagai orang-orang yang bekerja di pasar. Kata Marpasar terdiri dari dua kata yaitu "mar" dan "pasar." Kata mar menunjuk pada kalimat aktif berupa ajakan atau himbawan, sedangkan pasar adalah setiap struktur yang memungkinkan pembeli dan penjual untuk menukar jenis barang, jasa dan informasi. Pertukaran barang atau jasa untuk uang adalah transaksi. Disamping pasar tempat bertemunya penjual dan pembeli, pasar juga tempat bertemunya transaksi pinjaman yang ditawarkan oleh lembaga keuangan baik bank maupun nonbank. ${ }^{10}$ Jadi "Marpasar" itu menunjuk pada orang-orang yang bekerja di pasar dengan berbagai jenis ragam usaha yang diperjual-belikan di Pasar. Akan tetapi dalam perkembangannya, istilah marpasar ini mengalami penyempitan makna. Hal ini disebabkan kecenderungan orang-orang Batak di pasar-pasar umum maupun pasar-pasar tradisional di pulau Jawa adalah mayoritas meminjamkan uang, maka kata Marpasar itu dimaknai secara sempit yaitu "berdagang uang" atau "meminjamkan uang" atau lebih tepat "membungakan uang."

7 Sonny Eli Zaluchu, "Strategi Penelitian Kualitatif Dan Kuantitatif Di Dalam Penelitian Agama", Evangelikal: Jurnal Teologi Injili dan Pembinaan Warga Jemaat, Volume 4, Nomor 1, Januari 2020, 34 .

${ }^{8}$ Charles W. Koller, Khotbah Ekspositori Tanpa Catatan (Bandung: Kalam Hidup, 1997), 20.

${ }^{9}$ Emzir, Metode Penelitian Kualitatif Analisis Data (Jakarta: PT Raja Frafindo Persada, 2016). 37-

38.

10Parlina, "Praktik Pinjaman Rentenir Dan Perkembangan Usaha Pedagang Di Pasar Prapatan Panjalin Majalengka, 126" 
Sudut pandang lain, Faried mengemukakan Marpasar itu sebagai pelepas uang (rentenir) usaha perseorangan yang memberi kredit/pinjaman berupa uang tunai, sumber dana berasal dari modal sendiri. Pelepas utang/rentenir adalah suatu jenis pekerjaan yang sesungguhnya tidak jauh berbeda dengan bank dan lembaga keuangan nonbank yang bergerak di bidang jasa pelayanan jasa simpan pinjam uang. ${ }^{11}$ Arti kata marpasar menjadi sama dengan rentenir (suatu istilah bahasa Inggris yang telah diadopsi menjadi bahasa Indonesia) yang berarti orang-orang yang mencari nafkahnya dengan membungakan uang). Orang-orang yang marpasar, yang meminjamkan uangnya dan membungakan itu adalah rentenir-rentenir baru di jaman ini yang tampilannya lebih santun dan cara meminjamkan uang yang mungkin lebih bersahabat, tanpa agunan. Sedangkan menurut Harjoni, rentenir digambarkan dengan orang atau kelompok yang mempunyai pekerjaan meminjamkan uang (atau juga dalam bentuk barang) kepada orang lain yang memerlukan dengan imbalan bunga tertentu yang telah ditetapkan oleh si renternir. ${ }^{12}$ Dari uraian arti marpasar, maka penulis merangkum arti kata marpasar dalam artikel ini yaitu orang yang bekerja mencari nafkah dengan cara membungakan uang kepada nasabah-nasabah di pasar-pasar tradisional, dan ketika melakukan transaksi modal utamanya didasarkan pada kesepakatan dua belah pihak baik bunga, jenis cicilannya dan durasi waktu yaitu oleh kedua belah pihak antara debitor (peminjam) dan kreditor (pemberi pinjaman) atas dasar sling percaya satu sama lain.

\section{Cara Kerja dan Transaksi Pelaku Marpasar}

Para pekerja Marpasar umumnya bekerja dengan carapergi ke pasar-pasar tradisional untuk mencari nasabah. Setelah itu mereka akan melakukan pendekatan kepada para pedagang di pasar dengan menawarkan uangnya kepada pedagang-pedagang yang ada di pasar. Mereka akanmelakukan pendekatan dengan mengobrol dan menawarkan jasa uang pinjaman kepada para pedagang yang dipasarbagi siapa yangmembutuhkan. Penulis pun mewawancarai informan $\mathrm{R}$ yang menekuni pekerjaan ini. Ia mengungkapkan setelah menawarkan jasa uangnya, maka para pekerja Marpasar akan melakukan transkasi didasarkan kesepakatan mengenai jumlah pinjaman, jumlah bunga, serta model membayar cicilannya baik dalam bentuk hari, minggu atau jumlah kelipatan dari uangnya.

Biasanya pihak kreditor (pemberi pinjaman) dan pihak debitor (pemimjam) ketika bertransaksi jumlah bunga serta model pembayaran yang utama dibahas oleh kedua belah pihak. Monang Siahaan mengemukakan, keistimewaan meminjam uang lewat rentenir yaitu kecepatan dan tanpa agunan, tetapi dari kedua hal tersebut yang lebih utama adalah kecepatan meminjam uang tanpa banyak syarat-syarat, pada saat dibilang butuh uang seketika itu uang diberikan rentenir. Sedangkan mengenai agunan tidak begitu menentukan, sebab bank pemerintah yang turun ke pasar tradisional sudah meminjamkan uangnya tanpa agunan, tetapi tidak begitu menentukan untuk meminjam uang, tetapi kecepatan yang menentukan uang pada saat belanja barang jam 03.00 WIB yang dibutuhkan.13

\section{Jumlah Bunga Pekerja Marpasar}

Pengamatan penulis serta hasil wawancara kepada para pelaku Marpasar, ketika meminjamkan uang kepada pihak peminjam, bunga yang dibebankan kepada debitor

${ }^{11}$ Wijaya Faried dan Soetatwo Hadiwigono, Lembaga-Lembaga Keungan Dan Bank (Yogyakarta: BPFE, 1995), 413.

${ }^{12}$ Harjoni \& Reza Fahmi, "Pembiayaan Permodalan Ideal Dalam Mengatasi Praktik Rentenir", JEBI Jurnal Ekonomi dan Bisnis Islam, Volume 3, Nomor 1, Januari - Juni 2018, 21.

${ }^{13}$ Monang Siahaan, Rentenir Penolong Pedagang Kecil? (Jakarta: PT Elex Media Kamputindo, 2014), 21. 
(peminjam) sekitar 20\%. Dengan mematok bunga sekitar 20\%, ini yang menyebabkan timbulnya streotif negatif dikalangan masyarat umum maupun lingkup gereja. Nugroho mengemukakan, dalam masyarakat umum, rentenir memiliki citra buruk sebagai lintah darat yang mengambil bunga dalam jumlah sangat besar dari pinjaman nasabahnya, akan tetapi rentenir tetaplah eksis di dalam masyarakat, mereka tetap menjadi alternatif di saat kebutuhan finansial sedang meningkat, bagi rakyat kecil, kredit dari rentenir inilah yang menguntungkan secara ekonomi, karena ketika mereka meminjam di Bank sebagai lembaga finansial formal, syarat yang dibutuhkan sangat rumit. ${ }^{14}$ Bunga yang dibebankan oleh para pelaku Marpasar kepada para peminjamsebesar 20\%, bahkan mungkin ada sebagian oknumoknum pekerja Marpasaryang membebankan bunga di atas 20\%. Akan tetapi pada umumnya para pekerja Marpasar, bunga $20 \%$ yang menjadi acuan mereka kepada para nasabahnya masing-masing. Tentunya ini didasarkan pada fakta di lapangan bahwa dari responden yang penulis wawancarai dengan pertanyaan, berapa bunga yang dibebankan kepada nasabah? Apa yang menjadi dasar utama dalam melakukan transaksi kepada para nasabahnya masing-masing. ${ }^{15}$ Para responden menjawab $20 \%$ bunga yang dipatok dan saling percaya menjadi point utama dalam bertransaksi.

Bunga yang dipatok para pekerja Marpasar kepada para nasabahnya berkisar 20\% bahkan ada yang lebih, dianggap merupakan hal yang wajar karena tidak adanya jaminan yang diberikan oleh peminjam. Mereka membebankan bunga di atas standar yang ditetapkan bunga bank agar keuangan mereka tetap bisa survive dalam menekuni ini. Siahaan menjelaskan, dalam dunia dagang/usaha mengambil untung sebesar 40\%, bahkan keuntungan dua kali lipat bahkan 10 kali lipat dianggap wajar atau sah-sah saja dan tidak termasuk riba, pengisap darah, dan lintah darat, tetapi bila meminjamkan uang dengan bunga sebesar $20 \%$ langsung dituding rentenir, riba, pengisap darah dan lintah darat. Rasanya kurang adil karena menjual barang dengan keuntungan besar disebut wajar saja sedangkan meminjam uang dengan mendapatkan keuntungan sebesar $20 \%$ disebut riba, pengisap darah, padahal dagang barang berupa emas, mobil, ternak dengan meminjam uang adalah masuk kelompok dagang/usaha yang saling mencari keuntungan dari pihak yang terlibat atas dagang/usaha tersebut, baik sebagai pedagang barang emas, maupun pembeli barang emas, demikian juga peminjam uang dengan yang meminjam uang. ${ }^{16}$

Biasanya para nasabah dalam melunasi pinjamannya sesuai dengan kesepakatan bersama oleh dua belah pihak. Adapun kecenderungan persepakatan dalam membayar utang oleh pihak debitur kepada pihak kreditor (pemberi pinjaman), dengan mencicil setiap hari sesuai jumlah awal yang telah disepakati. Ada juga sebagian para nasabah yang meminjam uang dengan langsung membayar utangnya bersamaan dengan bunganya.

\section{Dasar Transaksi Pekerja Marpasar Dengan Para Nasabah}

Debitur (peminjam) bila ingin meminjam uang kepada lembaga keuangan seperti bank atau koperasi harus ada jaminan seperti surat rumah, mobil atau surat berharga sejenisnya. Bank memang membuat aturan seperti itu untuk mengantisipasi para debitur (peminjam) bila terjadi kemacetan dalam pinjamannya. Salah satu risiko perbankan dalam pemberian kredit adalah kredit bermasalah. Kredit bermasalah adalah kredit yang tidak mampu diselesaikan sebagaimana mestinya oleh debitur terhadap kreditur atau melampaui batas waktu yang telah ditentukan sesuai dengan perjanjian kredit yang telah disepakati 2001), 86 .

${ }^{14}$ Heru Nugroho, Uang Rentenir Dan Hutang Piutang Di Jawa (Yogyakarta: Pustaka Belajar,

${ }^{15}$ Wawancara dilakukan dengan whatsap, telepon kepada 6 orang responden diwaktu yang berbebeda pada hari Kamis, 4 Januari 2020.

16Siahaan, Rentenir Penolong Pedagang Kecil? 
bersama. Rasio kredit bermasalah yang tinggi mengakibatkan bank kehilangan kemampuannya dalam menghasilkan laba yang optimum dari kegiatan pokoknya tersebut. Hal ini salah satunya karena pendapatan operasional dari pemberian kredit sangat kecil. Bunga yang seharusnya diterima oleh bank dari penyaluran kredit tidak diterima secara penuh. ${ }^{17}$

Berbeda halnya bila meminjam uang kepada para pelaku Marpasar, modal saling percaya adalah hal yang utama terjadinya transaksi antara peminjam dan pemberi pinjaman. Dengan bermodalkan "saling percaya"tidak jarang para nasabah sering kabur membawa lari uang yang dipinjamkannya. Sebagaimana dikemukakan oleh Ilas Korwadi Siboro, kebanyakan dari rentenir yang meminjamkan uang ke masyarakat biasanya juga bisa mengalami kerugian, seperti halnya masyarakat tersebut tidak bisa membayar atau masyarakat tersebut sudah melarikan diri dari tanggung jawabnya. Pihak rentenir (pekerja Marpasar) terpaksa harus mengikhlaskan dan merelakan uangnya hangus begitu saja, karena tidak bisa berbuat apa-apa lagi karena masyarakat yang meminjam uang tersebut tidak diketahui dimana keberadaanya. ${ }^{18}$

\section{Plus-Minus dari Pekerjaan Marpasar}

Tidak bisa dipungkiri pekerjaan Marpasar telah menjadi alternatif pilihan oleh sebagian orang sebagai mata pencarian utama di tengah-tengah masih terjadinya pengangguran. Walaupun era pemerintahan Presiden Jokowi mengungkapkan angka pengangguran ada signifikasi penurunan, namun tetap juga angka pengangguran masih tingggi di tengah sulitnya mencari pekerjaan. Berdasarkan data dariBadan Pusat Statistik (BPS) mencatat tingkat pengangguran terbuka (TPT) pada Februari 2019 berada di level $5,01 \%$. Angka ini mengalami penurunan jika dibandingkan dengan periode yang sama tahun 2018. Kepala BPS Suhariyanto mengatakan jumlah TPT pada Februari 2019 sebanyak 6,82 juta atau setara dengan 5,01\% dari total angkatan kerja. Tingkat pengangguran terbuka ada Februari terus turun menjadi 5,01\%, tahun 2018 sebesar 5,13\%."19

Adanya signifikansi jumlah penurunan angka pengangguran dipengaruhi oleh daya serap dibidang perdagangan. Pekerjaan Marpasar dapat dikategorikan bagian dari sistem perdagangan. Marpasar menjadi kontra baik dikalangan masyarakat umum maupun di gereja, karena publisitas hal-hal negatif dari Marpasar ini lebih menonjol dibandingkan dengan publisitas positifnya. Adapun sisi positif dari pekerjaan Marpasar yaitu: pertama, ketika meminjam kepada para pekerja Marpasar, pihak debitor kecenderungan tidak dibebankan agunan, sedangkan kalau meminjam ke bank syarat agunan selalu dibebankan. Kedua, kecepatan pelayanan pekerja Marpasar dalam mencairkan pinjamannya kepada pihak debitur (peminjam) menjadi nilai plus dibandingkan bila meminjam kepada bank yang cenderung ribet dalam hal administrasi. Ketiga, pekerja Marpasar yang menjemput "bola," maksudnya kecendrungan mereka yang mendatangi calon-calon nasabah untuk menawarkan jasa pinjam uang. Tidak seperti lembaga keuangan seperti bank, koperasi, fungsi kerjanya lebih cenderung hanya menunggu calon nasabahnya. Keempat, pihak debitur diuntungkan dengan jam kerja para pekerja Marpasar yang tidak ada keteraturan jam

\footnotetext{
${ }^{17}$ Naasyiatul Lailaa and Elisabeth Penti, "Penyaluran Kredit Usaha Rakyat Bagi Kinerja Bank Pembangunan Daerah" Vol. 21, No. 1 (2018): 24.

${ }^{18}$ Ilas Korwadi Siboro, "Rentenir (Analisis Terhadap Fungsi Pinjaman Berbunga Dalam Masyarakat Rokan Hilir Kecamatan Bagan Sinembah Desa Bagan Batu," Jom Fisip Vol 2 No 1, (2015), 2.

19“Jumlah Pengangguran RI Turun Jadi 6,82 Juta Orang," Agustus 29, 2019, https:/ / finance.detik.com/ berita-ekonomi-bisnis/d-4537694/jumlah-pengangguran-ri-turun-jadi682-juta-orang.
} 
kerjanya. Saat butuh dana dalam suasana mendesak, kehadiran pekerja Marpasar selalu ada. Kelima, modal transaksi antara debitur dan kreditor hanya berupa kepercayaan kepada dua belah pihak. Frans mengemukakan, biasa pelepas uang mengetahui sedikit banyak latar belakang dari para peminjam/nasabahnya. Hubungan yang dekat ini menciptakan rasa saling percaya antara peminjam dengan pelepas uang. Kepercayaan inilah yang menjadi modal utama sehingga aktivitas peminjaman uang yang dilakukan oleh pelepas uang dapat berjalan dengan baik. ${ }^{20}$

Selain sisi positif dari pekerjaan Marpasar, sisi minus pun mewarnai pekerja Marpasar yang membuat terbentuknya streotif negatif dari pelaku Marpasar. Sisi minus tersebut yaitu: pertama, pihak debitur (peminjam) terkadang menerima perlakuan kasar dari sebagian oknum berupa dimarahi atau dicaci maki apabila terlambat membayar cicilan pinjamannya. ${ }^{21}$ Kedua, adanya oknum pelaku Marpasar yang bermain nakal dengan mengelabui nasabahnya bahwa iuran pinjamannya dicurangi. Ketiga, sebagian oknum pelaku Marpasar mengambil secara paksa barang berharga debitor (peminjam).

\section{Perspektif Alkitab Tentang Membungakan Uang}

Perdebatan seputar membungakan uang dianggap dosa didasarkan pada adanya ayat-ayat dalam Alkitab. Dalam Keluaran 22:25 menulis "Jika engkau meminjamkan uang kepada salah seorang dari umat-Ku, orang yang miskin di antaramu, maka janganlah engkau berlaku sebagai seorang penagih hutang terhadap dia: janganlah kamu bebankan bunga uang kepadanya." Apabila membaca keseluruhan Keluaran pasal 22, pasal ini mengatur mengenai pengaturan harta serta perlindungan kepada keluarga yang miskin di lingkup sesama orang Israel sendiri. Allah ingin menekankan kepada bangsa Israel agarsikap kepedulian dalam hal berbagi khususnya di antara mereka sendiri. Dalam bahasa Ibrani kata "uang" menggunakan kata " "כְָּּ (ke sep), bila diterjemahkan perak, atau emas, uang.22 Sedangkan kata "bunga uang" menggunakan (kə) nō šeh $)$ ), artinya menjadi kreditor. Jika ditafsir ayat ini mengemukakan bahwa Allah melarang umat Israel agar jangan ada diantara mereka bertindak sebagai kreditor (pemberi pinjaman) diantara sesama kaumnya sendiriapalagi bila membebankan bunga kepada sesama terutama dalam sandang pangan. Alkitab terjemahan New America Standar menulis " you are not to act as a creditor to him; you shall not charge." Alkitab Penuntun Hidup Berkelimpahan memberikan penjelasan mengenai ayat ini bahwa Allah melarang meminta bunga atau uang yang dipinjamkan kepada mereka yang kekurangan untuk menyediakan kebutuhan pokok. Allah ingin mencegah orang miskin diperas oleh golongan kaya. Akan tetapi, hukum ini tidak melarang peminjaman uang dengan bunga yang wajar kepada orang bukan Israel dengan tujuan komersial (Ul.. 23:19-20; Mat. 25:27; Luk.19:23)."23

Tuhan melarang orang Israel membebankan bunga kepada sesama hanya diperuntukkan kepada orang yang miskin yang tidak memiliki apa-apa. Malahan Allah berkata "Jika engkau sampai mengambil jubbah temanmu sebagai gadai, maka haruslah engkau mengembalikannya sebelum matahari terbenam" (Kel. 22:26). Eberle mengemukakan, Allah memerintahkan orang-orang Ibrani untuk tidak mengenakan bunga

${ }^{20}$ Ratna Wilis Frans E. Panjaitan, Nofrion, "Praktik Pelepas Uang/Rentenir Di Nagari Lubuk Basung Kabupaten Agam Sumatera Barat,” Jurnal Buana Vol. 2 No, 1 (2018): 45.

21Siboro, "Rentenir (Analisis Terhadap Fungsi Pinjaman Berbunga Dalam Masyarakat Rokan Hilir Kecamatan Bagan Sinembah Desa Bagan Batu."

${ }^{22}$ Pada zaman Perjanjian Lama, orang Israel tidak mengenakan uang kertas atau uang logam sebagai alat tukar mereka, tetapi emas dan perak yang dipakai untuk jual beli dalam bertransaksi. Alkitab Edisi Studi (Jakarta: LAI, 2010), 146.

${ }^{23}$ Alkitab Hidup Berkelimpahan, (Malang: Gandum Mas, 200), 123. 
saat mereka meminjamkan uang kepada sesama. Meski demikian, mereka dapat mengenakan bunga saat mereka pinjamkan uang kepada orang-orang yang bukan Ibrani. Allah bahkan menjelaskan bahwa kemampuan untuk meminjamkan sebagai berkat hingga Dia akan memampukan mereka untuk melakukannya saat mereka menaati perintah-Nya (Ul. 28:12-13). ${ }^{24}$

Pelarangan Tuhan agar jangan membungakan uang diantara sesama umat Israel karena mereka masih hidup dalam zona pengembaraan yang tidak memiliki mata pencarian yang pasti. Tuhan melakukan hal ini untuk menjaga kerukunan serta kesejahteraan di antara sesamaumat Israel agar tidak terjadi ketimpangan sosial di antara mereka. Tentunya ini selaras dengan nilai lain yang kuat ditanamkan dalam budaya Ibrani yaitu tentang hidup berbelas kasihan dan pemeliharaan kepada janda, yatim piatu dan kaum miskin. Itu merupakan nila-nilai cara masrakat Ibrani kuno, dengan merawat orang yang lanjut usia, para yatim piatu, para janda, dan kaum miskin. Nilai-nilai sosial ini tidaklah ditegakkan oleh pemerintah, namun hal itu adalah tekanan budaya yang ditempatkan di atas pundak setiap individu. ${ }^{25}$

Tuhan melarang penarikan bunga diantara sesamaumat Israel untuk pembentukan citra diri atau identitas sebuah bangsa yang dipilih Tuhan dalam memperkenalkan Tuhan yan benar bersamaan dengan sifat-sifat-Nya kepada bangsa nonIsrael. Perintah Allah yang tegas agar tidak ada praktik membungakan uang kepada sesama umat Israel sebagai caraNya dalam mendesain dan memperlihatkan, kuatnya belas kasihan serta empati di antara sesama umat Israel untuk ikut bertanggung jawab agar tidak terjadi ketimpangan sosial. Nila-nilai seperti ini juga sebagai pembeda kepada penganut agama pagan kuno yang miskin akan belas-kasihan. Nila-nilai tadi sepenuhnya bertentangan dengan nilai-nilai agama pagan kuno yang tidak menawarkan motif untuk beramal." 26

Larangan Tuhan agar umat Israel jangan membebankan bunga kepada sesama mereka terlihat dari keseriusan Tuhan dengan berungkali berfirman akan hal ini. Dalam kitab Imamat 25:36-37 pun Ia berfirman "Janganlah engkau mengambil bunga uang atau riba dari padanya, melainkan engkau harus takut akan Allahmu, supaya saudaramu dapat hidup di antaramu. Janganlah engkau memberi uangmu kepadanya dengan meminta bunga, juga makananmu janganlah kauberikan dengan meminta riba" (Im. 25:36-37). Dalam terjemahan Alkitab Bahasa Indonesia Sehari-Hari, apabila di antara sesama orang Israel ada yang jatuh miskin dan tak dapat membiayai hidupnya, maka mereka sebagai sesama satu rasdan satu bangsa, ditentang Tuhan memungut bunga dari yang meminjam. Justru sebaliknya, Allah menghimbau agar umat Israel bergotong royong atau saling bahu membahu untuk membantu nafkah hidup yang berkekurangan agar kelangsungan hidup terjaga satu sama lain sebagaimana mereka dulu menjadi orang asing di Mesir.

Tafsiran Matthew Henry Commentary mengemukakan sebaliknya, dalam perhatian kepada sesama umat Tuhan, umat yang yang berkelimpahan harus menyokong mereka yang sedang dilanda kegagalan panen dengan meminjamkan tanpa bunga. Justru mereka yang jatuh miskin harus diperlakukan secara manusiawi. Karena seluruh tanah Kanaan kelak akan menjadi milik pusaka mereka bersama (Israel). ${ }^{27}$ Karena itu masyarakat Ibrani mempunyai banyak cara untuk menyediakan kebutuhan bagi yang memerlukan. Mereka didorong memberikan sedekah kepada yang miskin, para petani diperintahkan untuk

${ }^{24}$ Harold R. Eberle, Kapitalisme Yang Berbelas Kasih Sebuah Nilai Kristen-Yahudi (Semarang: Jendela Cakrawala Media, 2014), 28.

${ }^{25}$ Eberle, Kapitalisme Yang Berbelas Kasih Sebuah Nilai Kristen-Yahudi , 23.

${ }^{26}$ Ibid. .

${ }^{27}$ Tafsiran Matthew Henry Commentary, versi elektronik. 
memungut tanaman mereka sekali, agar orang asing, para janda dan yatim piatu bisa dengan bebas mengumpulkan apa yang masih tersisa (Ul. 24:19-21).

Larangan Tuhan kepada semua umat Israel agar jangan mengambil bunga di antara sesama mereka tidak hanya ditunjukkan berupa emas, perak atau uang, tetapi Allah pun melarang mereka membebankan bunga baik berupa makanan maupun barang bila ada sesama yang meminjam. Hal ini dipertegas Allah dengan menyatakan "Janganlah engkau membungakan kepada kepada saudaramu, baik uang maupun bahan makanan atau apapun yang dapat dibungakan" (Ul. 23:19). Ungkapan Allah ini memperlihatkan bahwa Ia menjaga betul agar tidak adanya ke-egoisan di antara sesama umat Israel, Ia mendorong mereka menjadiumat yang menumbuhkan empati dan kepedulian agar timbul rasa sepenanggungan dan mengingat bagaimana mereka pernah menderita di Mesir. Tafsiran Wyclife mengemukakan tentang ayat ini berkaitan dengan "HukumTentang Kemakmuran" maksudnya adalah orang-orang Israel yang jatuh miskin terlindung dari pemerasan oleh para saudara sebangsa yang lebih kaya melalui larangan untuk tidak membungakan uang. Bunga boleh diambil dari orang asing (nonIsrael), karena uang yang dipinjamkan kepada mereka bukan untuk mengatasi kemiskinan, tetapi untuk modal yang bisa dipakai oleh pedagang keliling ini untuk keuntungan mereka sendiri."28

Pendapat senada dikemukakan oleh Walter C Kaiser Jr, alasan bagi pelarangan yang keras terhadap pengenaan riba adalah karena sudah terlalu banyak kejadian di Israel yang menggunakan metode ini untuk menghindar dari kaum miskin dan sesama warga mereka sendiri. Ulangan 23:20 mengatakan, "dari orang asing boleh engkau memungut bunga." Nampaknya ini merupakan hal yang sama dengan riba untuk hutang bisnis atau investasi, yang juga diperbolehkan. ${ }^{29}$ Pertanyaan mendasar, apakah boleh membungakan uang bila dikaitkan dimasa sekarang? Tentu bisa, sebab dalam masa-masa modern, secara prinsip hutang diperlukan sebagai sarana untuk meningkatkan modal yang dipakai orang untuk bekerja. Jika seseorang tidak memiliki modal yang lebih besar, maka industri tertentu itu mungkin tidak mampu mendatangkan pendapatan yang meningkat. Namun pada masa lalu, perhatian seperti itu tidak sebesar yang terjadi pada masa-masa modern ini. Maka, pinjaman-pinjaman pada waktu itu hampir khusus untuk meringankan kemelaratan dan kelaparan yang hebat. ${ }^{30}$

\section{Menurut Kitab Nehemia dan Yehezkiel}

Apabila membaca kitab Perjanjian Lama, Allah secara konsisten pelarangan bunga dikenakan khususnya dalam interaksi sosial bagi sesama Israel sebagai satu bangsa dan satu ras. Larangan Tuhan agar umat Israel tidak membebankan bunga. Dalam Yehezkiel pasal 18, "tidak memungut bunga dan riba" kurang lebih sampai tiga kali Allah mengulang pada pasal ini. Penekanan Allah agar bangsa Israel tidak memungut bunga menandakan keseriusan-NYA. Akan tetapi intisari utama Allah pada pasal ini bukan menyoroti mengenai pemungutan bunga atau riba, tetapi seruan Allah agar hidup mengenakan belaskasihan menjadi perhatian Tuhan. Lagi pula Allah melarang memungut bunga di antara sesama mereka, karena kondisi mereka pada saat zaman Yehezkiel sedang terjajah oleh Babel. Baxter mengungkapkan, Yehezkiel seorang di antara 10.000 tawanan yang diangkut ke Babel oleh raja Nebukadnezar pada saat Zedekia, raja Yehuda yang terakhir, mulai memerintah 11 tahun lamanya di Yerusalem. ${ }^{31}$

${ }^{28}$ Tafsiran Alkitab Wyclife, versi Elektronik.

${ }^{29}$ Walter C Kaiser Jr, Ucapan Yang Sulit Dalam Perjanjian Lama (Malang: SAAT, 2015), 65.

${ }^{30}$ Walter C Kaiser Jr, Ucapan Yang Sulit Dalam Perjanjian Lama.

31J. Sidlow Baxter, Menggali Isi Alkitab 2 (Jakarta: Yayasan Komunkasi Bina Ksih/OMF, 2002),

268. 
Apabila diselidiki secara historis, pada masa Yehezkiel, kehidupan bangsa Israel mengalami kesukaran dalam berbagai hal di antaranya kesulitan secara sandang pangan karena mereka berada dalam pembuangan. Mereka ditawan di Babel karena perbuatan mereka yang tidak mau bertobat, hatinya tergila-gila kepada berhala, sehingga hidupnya makin bertambah merosot kedalam tahayul dan kejahatan. ${ }^{32}$ Kitab Yehezkiel memang menyinggung tentang pembungaan uang dan makan riba sebagai sebuah perintah Allah yang tidak sukai. Namun larangan membungakan uang dan makan riba bila dibaca secara keseluruhan dari Yehezkiel 18:7-8, 13, 17 bukanlah hal yang mendasar pada pasal ini, tetapi pokok yang mendasar dari Yehezkiel pasal 18 adalah bahwa dosa itu merupakan tanggung jawab personal pribadi kepada Allah. Yehezkiel mengemukakan ini karena ia melihat dan mengamati adanya paradigma orang Israel bahwa ada ketidakadilan Allah karena menghukum orang yang bersalah hingga ke beberapa generasi. Hill mengemukakan, ajaran Yehezkiel tentang tanggung jawab perseorangan dalam pasal 18 membuktikan ketidakbenaran amsal "anggur masam" yang sangat popular dikalangan orang Israel sebagai ungkapan yang fatalis yang tidak berpengharapan sehubungan dengan keadaan gawat mereka mengingat hukuman Allah yang akan datang dan keputusan Allah untu mencurahkan murka yang sepertinya tidak adil. Orang Yehuda telah melemparkan kesalahan kepada generasi-generasi sebelumnya dengan mengatakan bahwa kesulitan mereka itu disebabkan oleh kelakuan dosa dari generasi-generasi sebelumnya." 33

Membungakan uang dan makan riba bukan hal yang esensial yang disoroti Allah khususnya dalam kitab Yehezkiel pada pasal 18. Karena itu inti utama dari kitab Yehezkiel dipasal ini adalah menekankan transendensi Allah, maksudnya ialah untuk menjelaskan bahwa kemahakuasaan Allah tidak dapat dibatasi oleh kegagalan umat-Nya. Maka janji pemulihan Israel tidak lagi tergantung pada syarat bahwa umat Tuhanharus lebih dulu bertobat, pemulihan ini merupakan tindakan kasih karunia Allah yang berbuahkan pertobatan. ${ }^{34}$ Tentu berbeda secara konteks dan keadaan dari kitab Yehezkiel dengan sekarang, karena Yehezkiel pasal 18 menekankan setiap orang Israel bertanggung jawab atas dosa yang diperbuat kepada Allah.

Larangan Tuhan dalam kitab Yehezkiel pasal 18 agar jangan membungakan uang dan makan riba, karena umat Tuhan saat itu sedang berada pada kondisi kesusahan karena Yerusalem dihancurkan dan dibuang ke Babel. Mereka dibuang ke Babel alasan utamanya bukan karena membungakan uang, tetapi hati dan tingkah laku mereka yang tidak mau bertobat kepada Tuhan karena hidup dalam penyembahan berhala. Oleh sebab itu kitab Yehezkiel pasal 18 ini berkaitan Allah menuntut pertanggungjawaban atas setiap dosa individu orang Israel di hadapan Allah.

Golongan yang kontra kerap juga menggunakan ayat Alkitab dari kitab Nehemia 5:7, 10. Dalam menentang pembungaan uang kepada mereka yang menekuni pekerjaan Marpasar. Adapun isi natsnya "Setelah berpikir masak-masak, aku menggugat para pemuka dan para penguasa. Kataku kepada mereka: 'Masing-masing kamu telah makan riba dari saudara-saudaramu!' Lalu kuadakan terhadap mereka suatu sidang jemaah yang besar. Juga aku dan saudara-saudaraku dan anak buahku telah membungakan uang dan gandum pada mereka. Biarlah kita hapuskan hutang mereka itu! Juga aku dan saudara-saudaraku dan anak buahku telah membungakan uang dan gandum pada mereka. Biarlah kita hapuskan hutang mereka itu!" (Neh. 5-7:10).

32J. Sidlow Baxter, Menggali Isi Alkitab 2.

${ }^{33}$ Andrew E. Hill, Survei Perjenjian Lama (Gandum Mas, 1998), 570-571.

${ }^{34}$ Ensiklopedia Alkitab Masa Kini Jilid II (Jakarta: Yayasan Komunikasih Bina Kasih/OMF, 2007), 555. 
Kata membungakan dalam bahasa Ibrani pada ayat ini menggunakan kata (nō šîm) bila diterjemahkan meminjam atau menjadi kreditor. ${ }^{35}$ Sedangkan kata riba pada

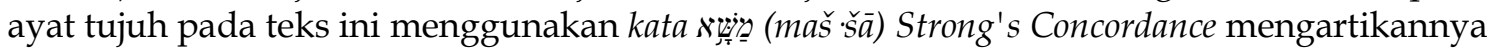
dengan arti "memperdaya atau menipu. ${ }^{36}$ Nehemia menyoroti bukan pada membungakan uangnya, namun ia melihat adanya sebagian orang Israel melakukan praktek-praktek penipuan serta pemerasan kepada mereka yang meminjam. Nehemia bersikap tegas bahkan sampai marah karena yang menjadi pelaku atau aktor utama praktek riba-ribaan ini adalah dari golongan imam-imam dan tua-tua Yahudi serta penguasa. Nehemia geram dengan situasi ini, mengingat seharusnya para imam dan tua Yahudi dan para penguasa bertindak meringkankan beban umat serta turut membantu mengangkat kesejahteraan dan pemulihan pasca pembungan yang dilakukan oleh kerajaan Media-Persia.

Kegeraman hati Nehemia melihat kondisi ini terlihat dari ayat sebelumnya yang tertulis "maka sangat marahlah aku ketika ku dengar keluhan mereka dan berita-berita itu" (Neh. 5:6). Kemarahan Nehemia terhadap ketidakadilan dan kejahatan yang dilihatnya dianggap sebagai kemarahan yang wajar. Justru kemarahan semacam ini menunjukan ketidakacuhannya terhadap penderitaan orang Israel yang tidak bersalah dan kekurangan. ${ }^{37}$ Hil pun mengemukakan, semangat yang sungguh-sungguh terhadap keadaan yang menyedihkan dari komunitas orang Yahudi yang sudah kembali di Yerusalem memberikan dorongan bagi kedua orang ini (Nehemia \& Ester) untuk mengadakan perjalanan dari Persia ke Palestina. Usaha mereka membaharui kehidupan beragama, sosial, dan ekonomi dari kota Ibrani itu berakar dalam rasa kebanggaan nasionalis akan tradisi nenek moyang bangsa Ibrani (Neh. 2:3) dan perhatian yang tulus untuk mempertahankan reputasi nama Yahweh di tengah-tengah perlawanan orang kafir (bdg. Ezr. 9. 1-15; Neh. 1:4-11). ${ }^{38}$

Penggambaran kitab Nehemia tentang sikap pribadinya dikarenakan kondisi yang ia lihat yaitu para imam, tua-tua Yahudi dan penguasa, menjadi pelaku dari pemerasan, dipandang sebagai sebuah kejahatan. Seharusnya imam-iman, tua-tua Yahudi, dan penguasa berfungsi menciptkan percepatan pemulihan dalam spiritual terlebih dalam peningkatan kesejahteraan kepada Israel. Uraian Keluaran 23:19, Imamat 25:36-37, Ulangan 23:19; Nehemia. 5:7, 10 dan Yehezkiel 18, menolak pekerjaan Marpasar hanya karena membungakan uang, tidaklah tepat jika dilihat dari prinsip hermeneutik karena ayat-ayat ini berbeda secara konteks, zaman, serta kultur geografi di masa kini. Selain itu Nehemia membina hubungan baik dengan raja dan harmonis dengan seluruh umat. Ia menyadari tanpa dukungan masyarakat, proyek besar tidak akan berjalan maksimal. Sehingga ia membangun optimisme yang tinggi agar masyarakat memberi dukungan penuh. ${ }^{39}$

Secara konteks ayat itu diperuntukkan hanya kepada sesama umat Israel di masa itu. Secara zaman, pelarangan Allah membungakan uang kepada sesama umat Tuhan, karena umat Israel kehidupan mereka masih dalam kategori penggembaraan. Corak kehidupan yang mengembara tentunya belum memiliki mata pencarian dan sistem perdagangan ekonomi di masa PL dengan masa kini tidaklah sama. Pelarangan Allah untuk tidak

35“Strong's Hebrew: 5383. נָשָָׁ (Nashah) -- to Lend, Become a Creditor," accessed September 12, 2019, https:// biblehub.com/hebrew/5383.htm.

36“Strong's Hebrew: 5378. נָשָָׁ (Nasha) -- to Beguile, Deceive," accessed September 12, 2019, https:/ / biblehub.com/hebrew/5378.htm.

${ }^{37}$ Alkitab Hidup Berkelimpahan, 723.

${ }^{38}$ Hill, Survei Perjenjian Lama, 367-368.

${ }^{39}$ Nasokhili Giawa, “Kepemimpinan Nehemia Dan Relevansinya Dalam Pengelolaan Perguruan Tinggi Keagamaan Kristen Di Indonesia," Jurnal Ilmiah Religiosity Entity Humanity (JIREH) 1, no. 2 (December 23, 2019): 149-160. 
membungakan uang kepada sesama bagian dari cara Tuhan dalam memprotektif semua umat Israel agar tidak ada yang melarat apalagi menderita dalam hal sandang pangan.

Bila di masa PL Allah melarang membebankan bunga kepada sesama mereka, lalu etiskah jika dimasa kini membungakan uang kesesama orang Kristen? Jawaban dari pertanyaan ini dilihat dari fungsi pinjaman itu dibuat untuk apa? Jika meminjam untuk pengembangan usaha, maka memberikan bunga yang dipinjam merupakan hal yang lumrah dalam kaitannya dengan bisnis. Yang penting pemberi pinjaman mematok bunga atau keuntungannya dalam tahap kewajaran. Makna dalam tahap kewajaran itu dapat dimaknai berdasarkan pendapat Eka Darmaputera, keuntungan yang dapat diperoleh penjual (pemberi pinjaman), tanpa mengeksploitasi kebutuhan pihak pembeli. Artinya: "kesempatan" pihak pembeli tidak dieksploitasi sebagai kesempatan untuk mengeruk keuntungan yang berlebihan bagi penjual. 40

\section{Menurut Perjanjian Baru}

Perjanjian Lama memuat mengenai ayat-ayat larangan membungakan uang yang dijadikan sebagai argumentasi teologis oleh yangkontra.Bagaimana dengan Perjanjian Baru mengenai isu ini? Jika dikaji, sepertinya PB memberikan suatu legalitas dalam membungakan uang. Bukti teologisnya ketika para pemungut cukai bertanya kepada Yohanes Pembaptis apa yang harus mereka perbuat? Kemudian Yohanes Pembaptis menjawab "Jangan menagih lebih banyak dari pada yang telah ditentukan bagimu" (Luk. 3:13). Apa yang diungkapkan oleh Yohanes Pembaptis mengindikasikan bahwa pelarangan praktek membungakan uang tidak ditentang. Pada zaman Perjanjian Baru, pemungut cukai adalah salah satu yang dibenci oleh para ahi-ahli Taurat dan orang Israel. Pemungut cukai dibenci karena menjadi "kaki tangan" Romawi untuk mengumpulkan persepuluhan bermacam-macam pajak yang dibebankan oleh Romawi kepada orang Yahudi. Kebencian ahli-ahli Taurat kepada para pemungut cukai, karena pemungut cukai cenderung memeras ditambah sentimen sikap fanatik orang Yahudi memandang bahwa para pemungut cukai menjalin kerja sama dengan orang kafir dalam hal ini pemerintah Romawi. ${ }^{41}$

Hal senada dikemukakan oleh Cecilia Wassen bahwa setelah reformasi di bawah Julius Caesar para pemungut cukai adalah para pegawai negeri yang dipekerjakan oleh negara, dan mereka sangat giat bekerja untuk Romawi dan rela disamakan dengan orang kafir bagi bangsanya. Para pemungut cukai memiliki tugas untuk memungut pajak pertanian, pajak distribusi, pajakpenangkapan ikan di danau Galilea, dan pajak-pajak kegiatan produktif lainnya, karena pemerintah tidak menetapkan jumlah pajak yang jelas untuk dibayarkan, hal tersebut membuka peluang untuk melakukan pemerasan. ${ }^{42}$ Memang ayat di atas tidak bisa dijadikan sebagai dasar teologis di PB untuk bersikap pro kepada golongan pelaku Marpasar. Namun, frasa kata "jangan menagih lebih dari pada yang telah ditentukan" dapat menjadi rujukan untuk pengimplementasian pelaku Marpasar ketika mereka melakukan transkasi kepada nasabah, agar memegang teguh dan komitmen pada perjanjian antara nasabah dan pemberi pinjaman untuk menyepakati besaran bunga beserta model pelunasan sebagaimana awal sebelum bertransaski. Henky H. Hetharia mengemukakan, penulis Lukas lewat cerita Yohanes ini meminta para pembacanya untuk meninggalkan kebiasaan memungut lebih banyak dari yang sudah ditetapkan di kalangan

${ }^{40}$ Eka Darmaputera, Etika Sederhana Untuk Semua: Bisnis, Ekonomi Dan Penatalayanan (Jakarta: BPK Gunung Mulia, 1990), 119-120.

${ }^{41}$ Ensiklopedia Alkitab Masa Kini Jilid I (Jakarta: Yayasan Komunikasi Bina Kasih/OMF, 2007), 285.

${ }^{42}$ Cecilia Wassen, "Jesus Table Fellowship with Toll Collectors and Sinners":Questioning the Alleged Purity Implications," Journal for the Study of the Historical Jesus Vol. 14 (Oktober 2016): 143-44. 
para pemungut cukai, dan kebiasaan menyalahgunakan kekuasaan di kalangan para prajurit untuk merampas dan memeras rakyat. Jangan menagih lebih banyak daripada yang telah ditentukan bagimu. Kata-kata yang sederhana ini menembus akar korupsi, mencari keuntungan, dan semua jerat yang mengulur untuk menghancurkan kesehatan, hakikat, akhlak serta kekuatan moral seorang individu maupun bangsanya. ${ }^{43}$

Lukas 19:23 menulis "Jika demikiaan, mengapa uangku itu tidak kauberikan kepada orang yang menjalankannya? Maka sekembalikuaku dapat mengambilnya serta dengan bunganya." Ayat yang masih linear dengan ini tertulis dalam Matius 25:27 "karena itu sudah seharusnya uangku itu kau berikan kepada orang yang menjalankan uang, supaya sekembaliku aku menerimanya serta dengan bunganya." Pertanyaannya, tepatkah ayat tersebut dijadikan sebagai dasar teologis untuk memberikan kesimpulan bahwa PB seperti mendukung pembungaan uang, sementara ayat tersebut dipahami sebagian orang tentang talenta. Mengenai nats ini Kornelius Ardianto Setiawan menjelaskan, banyak orang yang berusaha memahami talenta dalam konteks kehidupan hari ini, dimana kata talenta mempunyai arti kemampuan atau bakat alamiah yang dimiliki seseorang. Sedangkan saat Yesus menyampaikan perumpamaan ini, pendengarnya memahami talenta itu sebagai sejumlah uang yang sangat banyak yang mungkin setara dengan gaji selama satu tahun. Memahami talenta sebagai bakat, tentunya akan mempersulit untuk menjelaskan makna perumpamaan ini secara keseluruhan. Karena dalam Lukas. 19:13; Matius. 25:27 disebutkan agar talenta (atau bakat) itu dapat dititipkan ke orang lain agar menghasilkan bunga. ${ }^{4}$

Berdasarkan uraian ayat di atas, membungakan uang bukanlah bertentangan atau pun keliru bila membaca nats di atas. Sebab apa yang Yesus ucapkan dalam perumpamaan, uanglah yang dimaksud apalagi frasa ungkapan "menjalankan uang dan menerima kembali bunganya" dari Lukas 19: 13 dan Matius 25:27. Apabila para pekerja Marpasar menjadikan ayat ini sebagai dasar teologis, bahwa tidak berdosa mencari nafkah dengan membungakan uang, maka hal itu harus diperhitungkan sebagai sebuah kebenaran. Mengingat di masa kini orang meminjam uang tujuannya untuk pengembangan usaha, dan pemberi pinjaman pun berhak memperoleh bunga atau keuntungan sesuai dengan nats di atas. Pendapat senada dikemukakan oleh Walter C Kaiser Jr, adalah masuk akal menyimpulkan bahwa dulu dan sekarang riba masih tetap disetujui karena hal-hal tersebut tidak berupaya untuk menghindari kewajiban seseorang kepada kaum miskin. Rumusan ini ditegaskan kembali melalui kiasan yang Yesus tujukan dan nampaknya merupakan persetujuan untuk mengambil riba bagi hal komersial dalam Matius 25:27 dan Lukas 19:23." 45

Hal yang perlu diperhatikan oleh pembaca di masa kini yakni penyebab tingginya kemiskinan di zaman PB bukan karena membungakan uang. Kemiskinan merupakan hal yang biasa di zaman Yesus, malahan lebih banyak jumlah yang miskin dibandingdengan orang kaya. Akan tetapi tingginya kemiskinan disebabkan karena penjajahan serta eksploitasi secara kejam. Romawi melakukan tindakan-tindakan represif dan eksploitatif terhadap bangsa yang dikolonialisasinya. Pemerintah Romawi merampas tanah yang seharusnya dimanfaatkan untuk pertanian rakyat lalu dibagikan kepada parapenguasa, militer dan pegawai lokalnya, dan juga untuk membiayai kepentingan pemerintahan lokal. ${ }^{46}$ Belum lagi bentuk pembebanan pajak-pajak semakin menambah daftar kesengsaraan

${ }^{43}$ Henky H. HethariaTifa Teolog, "Korupsi Dalam Perspektif Etika Kristen," Tifa Teolog Vol. 2, No 2, (2012): 11-12.

${ }^{44}$ Kornelius Ardianto Setiawan, "Berkhotbah Dari Perumpamaan," Jurnal Theologia Aletheia Vol. 7. No 13, (2005): 8.

${ }^{45}$ Walter C Kaiser Jr, Ucapan Yang Sulit Dalam Perjanjian Lama.

${ }^{46}$ Thobias A. Messakh, Konsep Keadilan Dalam Pancasila (Salatiga: Satya Wacana Univeristy Press, 2007), 198. 
Yahudi. Purwanto mengemukakan pajak-pajak tersebut dibayarkan dalam tiga bentuk, yaitu uang, persentasi darihasil panen atau ternak, atau kerja paksa. Selain pajak dari hasil panen, pemerintah Herodes juga mengenakan "pajak kepala," dimana setiap laki-laki berusia empat belas tahun ke atas dan setiap wanita berusia di atas duabelas tahun dikenai pajak satu dinar (sekitar upah harian buruh).47

\section{Kesimpulan}

Marpasar adalah istilah sebutan dari bahasa Batak yang didefinisikan sebagai pekerjaan yang membungakan uang. Pro-kontra tentang Marpasar ditanggapi secara berbeda-beda dengan argumentasi teologis masing-masing. Pekerjaan Marpasar menjadi kontra karena publitas hal-hal negatif di masyarakat amat kuat dibanding sisi positif-nya. Pandangan stereo type buruk di masyarakat sebagai lintah darat yang mengeksploitasi rakyat miskin dengan cara menarik bunga yang sangat tinggi, tidaklah selalu benar hanya karena ada oknum pelakunya. Menggeneralisir pekerja Marpasar lintah darat dan sarat dengan pemerasan kurang bijak apalagi sampai melabeli sebagai manusia penuh dosa. Bila pihakpihak yang kontra menolak pekerjaan Marpasar dengan menyodorkan dalil-dalil ayat Firman Tuhan, tentu jika dikaji secara prinsip hermeneutik secara zaman, konteks, dan kultur geografi berbeda dengan masa kini. Bila di zaman Alkitab orang berhutang untuk menutupi kemelaratan dan kesusahan hidup, maka di masa kini orang berhutang cenderung pada pengembangan bisnis atau usaha. Secara biblika Marpasar sah-sah saja dilakukan dimasa kini, karena Alkitab pun menyetujui akan hal ini. Alasan lain Marpasar lumrah karena para nasabah yang meminjam uang digunakan untuk modal pengembangan usahanya.

Yang harus diperhatikan oleh pihak pelaku Marpasar ketika memberikan bunga pinjaman harus dalam tahap kewajaran. Tahap kewajaran itu tidak sampai mencekik atau membuat peminjam menjadi melarat, terlebih tidak membuat beranak pinak bunga pinjaman uang. Tentang hal ini pun Keisler mengemukakan, tentu saja semua moralitas mengutuk riba uang yang terlampau tinggi. Amsal 28:8 memperingatkan, orang yang memperbanyak hartanya dengan bunga yang melampaui batas. Mengumpulkan harta itu untuk orang lain, yang mempunyai belas kasihan kepada orang-orang lemah.48 Dalam terjemahan Alkitab Bahasa Indonesia Masa Kini menulis “Siapa menjadi kaya karena rente dan menggeruk keuntungan sebanyak-banyaknya, kekayaannya akan jatuh kepada orang yang berbelas-kasihan terhadap orang miskin" (Ams. 28:8 BIMK). Para pekerja Marpasar jangan juga sampai menggunakan hal-hal yang kotor demi mengeruk keuntungan agar memperkaya diri dan membuat nasabahnya melarat.

Apabila ada jemaat-jemaat dalam gereja lokal yang berkecimpung dalam pekerjaan Marpasar, maka gereja atau gembala sidang tidak boleh menjadi hakim apalagi sampai melabeli mereka sebagai pendosa. Sebaliknya, gereja mengadakanpendekatan pastoral dengan menghimbau agar jangan mematok bunga yang mengarah pada pemerasan kepada para nasabah. Berikan juga bimbingan pastoral bahwa citra diri sebagai lintah darat yang "melekat" akan terkikis secara perlahan-lahan dalam diri setiap pekerja Marpasar. Tujuannya agar mereka merasa gereja tidak berpandangan yang sama sebagaimana pandangan umum yang terlanjur melabeli dengan sisi negatifnya.

${ }^{47}$ Edi Purwanto, “Meneropong Ketimpangan Sosial Ekonomi Masyarakat Yahudi Pada Zaman Yesus Melalui Lensa Teori Sosial"," Stulos Vol. 17, N. 1 (2019), 100.

${ }^{48}$ Walter C Kaiser Jr, Ucapan Yang Sulit Dalam Perjanjian Lama. 


\section{Rujukan:}

Darmaputera, Eka. Etika Sederhana Untuk Semua: Bisnis, Ekonomi Dan Penatalayanan. Jakarta: BPK Gunung Mulia, 1990.

Dedy Mulyana. No Metode Penelitian. Bandung: Rosdakarya, 2002.

Edi Purwanto. "Meneropong Ketimpangan Sosial Ekonomi Masyarakat Yahudi Pada Zaman Yesus Melalui Lensa Teori Sosial"." Stulos Vol. 17, N (2019).

Emzir. Metode Penelitian Kualitatif Analisis Data. Cetakan ke. Jakarta: PT Raja Frafindo Persada, 2016.

Frans E. Panjaitan, Nofrion, Ratna Wilis. "Praktik Pelepas Uang/Rentenir Di Nagari Lubuk Basung Kabupaten Agam Sumatera Barat." Jurnal Buana Vol. 2 No, (2018).

Giawa, Nasokhili. "Kepemimpinan Nehemia Dan Relevansinya Dalam Pengelolaan Perguruan Tinggi Keagamaan Kristen Di Indonesia." Jurnal Ilmiah Religiosity Entity Humanity (JIREH) 1, no. 2 (December 23, 2019): 149-160.

Harold R. Eberle. Kapitalisme Yang Berbelas Kasih Sebuah Nilai Kristen-Yahudi (Semarang: Jendela Cakrawala Media, 2014), 28. Semarang: Jendela Cakrawala Media, 2014.

Henky H. HethariaTifa Teolog. "Korupsi Dalam Perspektif Etika Kristen." Tifa Teologi Vol. 2, No (2012).

Heru Nugroho. Uang Rentenir Dan Hutang Piutang Di Jawa. Yogyakarta: Pustaka Belajar, 2001.

Hill, Andrew E. Survei Perjenjian Lama. Gandum Mas, 1998.

Ilas Korwadi Siboro. "Rentenir (Analisis Terhadap Fungsi Pinjaman Berbunga Dalam Masyarakat Rokan Hilir Kecamatan Bagan Sinembah Desa Bagan Batu." Jom Fisip Vol 2 No O (2015).

J. Sidlow Baxter. Menggali Isi Alkitab 2. Jakarta: Yayasan Komunkasi Bina Ksih/OMF, 2002.

Koller, Charles W. Khotbah Ekspositori Tanpa Catatan. Bandung: Kalam Hidup, 1997.

Kornelius Ardianto Setiawan. "Berkhotbah Dari Perumpamaan." Jurnal Theologia Aletheia Vol. 7. No (2005).

Lailaa, Naasyiatul, and Elisabeth Penti. "Penyaluran Kredit Usaha Rakyat Bagi Kinerja Bank Pembangunan Daerah" 21, no. 1 (2018): 23-42.

Nurhadi. “Bunga Bank Antara Halal Dan Haram." Nur El-Islam 4 No 2 (n.d.).

Parlina, Yeyen. "Praktik Pinjaman Rentenir Dan Perkembangan Usaha Pedagang Di Pasar Prapatan Panjalin Majalengka." Inklusif (Jurnal Pengkajian Penelitian Ekonomi Dan Hukum Islam) 2, no. 2 (2017): 100.

Siahaan, Monang. Rentenir Penolong Pedagang Kecil? Jakarta: PT Elex Media Kamputindo, 2014.

Thobias A. Messakh. Konsep Keadilan Dalam Pancasila. Salatiga: Satya Wacana Univeristy Press, 2007.

Walter C Kaiser Jr. Ucapan Yang Sulit Dalam Perjanjian Lama. Malang: SAAT, 2015.

Wassen, Cecilia. "Jesus Table Fellowship with Toll Collectors and Sinners":Questioning the Alleged Purity Implications." Journal for the Study of the Historical Jesus Vol. 14 (O (n.d.).

Wijaya Faried dan Soetatwo Hadiwigono. Lembaga-Lembaga Keungan Dan Bank. Yogyakarta: BPFE, 1995.

Alkitab Hidup Berkelimpahan. Cetakan ke. Malang: Gandum Mas, 200AD.

Ensiklopedia Alkitab Masa Kini Jilid I. Jakarta: Yayasan Komunikasi Bina Kasih/OMF, 2007.

Ensiklopedia Alkitab Masa Kini Jilid II. Jakarta: Yayasan Komunikasih Bina Kasih/OMF, 2007.

"Jumlah Pengangguran RI Turun Jadi 6,82 Juta Orang."

"Strong's Hebrew: 5378. נָשָָׁ (Nasha) -- to Beguile, Deceive."

"Strong's Hebrew: 5383. דָשָָׁ (Nashah) -- to Lend, Become a Creditor." 